\title{
Attacking the disease spiral in chronic obstructive pulmonary disease
}

\author{
Michael I Polkey and John Moxham
}

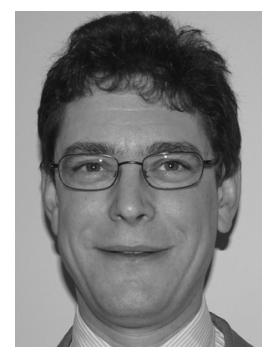

Michael I Polkey PhD FRCP, Consultant Physician and Reader in

Respiratory Medicine,

Respiratory Medicine

Laboratory, Royal Brompton Hospital, London

John Moxham MD FRCP, Professor of Respiratory Medicine, Respiratory Muscle Laboratory, King's College Hospital, London

This article is based on the

Linacre Lecture given at the Royal College of

Physicians on 13 February 2006 by Michael Polkey

Clin Med 2006;6:190-6
ABSTRACT - Chronic obstructive pulmonary disease (COPD) is the commonest respiratory cause of mortality and morbidity in adults in the UK. Although the condition is initially a pulmonary one, data exist to support the concept that factors associated with COPD, including immobility, gives rise to secondary effects, including a quadriceps myopathy, which in turn cause anaerobic metabolism at low work rates. This, through bicarbonate buffering, leads to $\mathrm{CO}_{2}$ retention which, because of constraints imposed by pulmonary mechanics, cause acidosis and dyspnoea. Various therapeutic strategies to reverse this spiral may be employed including pulmonary rehabilitation, quadriceps strength training and surgical or bronchoscopic lung volume reduction.

KEYWORDS: chronic obstructive pulmonary disease, lung volume reduction, pulmonary rehabilitation, quadriceps

Chronic obstructive pulmonary disease (COPD) is a common and serious problem. It is currently the fourth leading cause of chronic morbidity and mortality in the USA and is predicted to rank fifth in the worldwide burden of disease by $2020 .{ }^{1}$ COPD is one of the few major chronic diseases that continues to increase in both prevalence and mortality rate. With the exception of smoking cessation, ${ }^{2}$ no intervention has been shown to reduce progression of the condition. Despite maximal medical therapy with inhaled steroids and bronchodilators, people with COPD are frequently symptomatic and may be admitted with acute exacerbation. As a consequence, every physician practising general internal medicine will regularly encounter patients with advanced COPD.

Although COPD is initially a pulmonary disease, two arguments exist to support the notion that a wholly pulmonary disease is not a useful construct when considering patients with advanced COPD. First, the cardinal index of airflow obstruction, the volume expired in the first second of a forced expiration $\left(\mathrm{FEV}_{1}\right)$, is a very poor guide to symptoms ${ }^{3}$ and a

This article will also appear in Horizons in Medicine Vol 18 which will be published later in the year. Please cite only from the Journal. relatively weak guide to mortality. ${ }^{4}$ Second, correction of the pulmonary abnormality by double lung transplantation fails to restore exercise performance to normal. ${ }^{5}$

From this basis, we have developed the concept of a disease spiral that seems to better suit the clinical path of patients with COPD. It is important to emphasise that, as with many medical ideas, the concept is merely a resynthesis of previously described ideas, but it has nevertheless been helpful in generating hypotheses for ongoing studies. The overall schema is shown in Fig 1.

\section{Does evidence exist to support the disease spiral?}

\section{Breathless on exertion}

Most physicians accept that patients with COPD experience dyspnoea on exertion. However, in a landmark paper, Killian and co-workers identified that a surprisingly high number of patients with COPD also experience symptoms of leg fatigue (see later). ${ }^{6}$ We revisited this problem and took the opportunity to study both cycle and treadmillwalking exercise. ${ }^{7}$ We found that during a walking task, the majority (about 75\%) of patients stopped walking because of dyspnoea alone, although a minority placed leg fatigue as an equal or more important cause of exercise limitation. For cycle exercise, the proportion of patients citing breathlessness alone as the cause of exercise limitation was diminished.

\section{Quadriceps myopathy}

It is reasonably well accepted that patients with COPD have quadriceps wasting and weakness. ${ }^{8}$ At a microscopic level, the changes associated with COPD are characterised by a loss of fatigue-resistant type I fibres and of oxidative enzymes ${ }^{9,10}$ without differences in capillarity or mitochondria. ${ }^{11}$ Interestingly, type II fibres seem to have reduced mechanical efficiency and consequently reduced power output for a given level of oxygen uptake. The importance of quadriceps involvement in COPD is demonstrated by its association with increased use of healthcare resources ${ }^{12}$ and 
Fig 1. Disease spiral in chronic obstructive pulmonary disease (COPD).

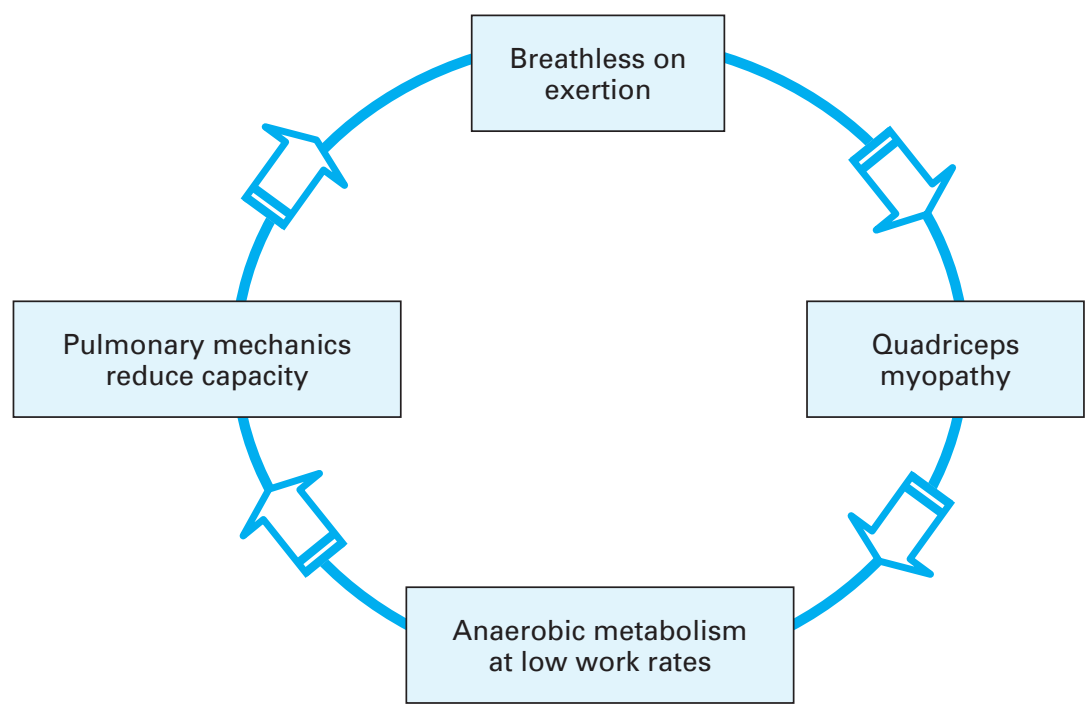

by the fact that, independently of $\mathrm{FEV}_{1}$, reduced quadriceps cross-sectional area is associated with a poorer prognosis (Fig 2). ${ }^{13}$

The origin of quadriceps weakness in COPD remains a matter of considerable controversy; for a more detailed review, see Couillard and Prefaut. ${ }^{14}$ The simplest hypothesis, and that used in the disease spiral, is simply that weakness arises as a result of immobility induced by the breathlessness. However, the picture is complicated by the clinical observation that quadriceps weakness may also complicate steroid administration, although this seems a less important problem in stable patients at the doses used in a conventional steroid trial. ${ }^{15}$ The picture is also clouded by the link between COPD and cachexia. Cachexia is certainly associated with a poor prognosis in COPD, ${ }^{16,17}$ but quadriceps weakness may occur in patients without nutritional depletion and this, therefore, cannot account entirely for quadriceps weakness. That disuse is a necessary condition for weakness is supported strongly by the finding that in patients with quadriceps muscle weakness, the strength of the diaphragm, adductor pollicus ${ }^{18}$ and abdominal muscles ${ }^{19}$ is normal; the relevance of these muscles is that they are continuously active, even in patients with the most severe disease. The presence of cofactors with immobility is not excluded by these data. In normal life, ${ }^{20}$ and especially during acute exacerbation, people with COPD have substantially reduced physical activity. It is well known that muscle strength is lost rapidly during disuse, ${ }^{21}$ and it is inevitable that quadriceps strength was shown recently to exhibit a significant reduction during admission for acute exacerbation of COPD. ${ }^{22}$ Spruit et al hypothesised a role for the cytokine interleukin 8 (IL-8) for muscle weakness in this
Fig 2. Risk of death in chronic obstructive pulmonary disease (COPD) stratified according to the volume expired in the first second of a forced expiration $\left(\mathrm{FEV}_{1}\right)$ and quadriceps bulk assessed as mid-thigh cross-sectional area (MTCSA) assessed using computed tomography (CT). If $\mathrm{FEV}_{1}$ is less than $50 \%$ predicted, then muscle wasting wields a more marked effect. Reproduced from Marquis et al (2002), reprinted with permission from the American Thoracic Society (C) American Thoracic Society. ${ }^{13}$

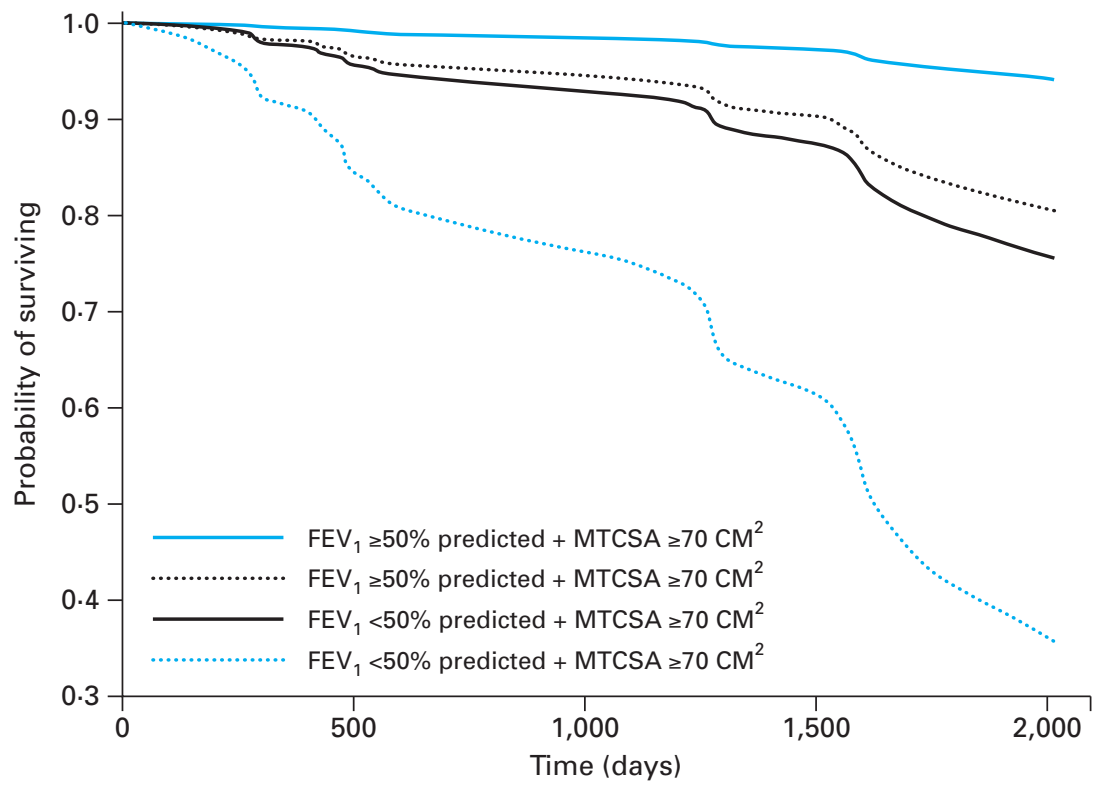


context, and other groups have separately suggested a role for tumour necrosis factor alpha (TNF- $\alpha)^{23}$ and interleukin 6 (IL-6). ${ }^{24}$ Other factors may also be relevant, in particular gene polymorphisms: we have established recently that, independent of lung function, patients with the II polymorphism of the gene that codes for angiotensin-converting enzyme is associated with reduced quadriceps strength in patients with COPD but not in age-matched controls. ${ }^{25}$

Recently, data have emerged to confirm that quadriceps fatigue is symptom-generating in COPD. Thirty-two patients underwent a constant-rate exercise test; magnetic stimulation of the femoral nerve was undertaken before and after the test. ${ }^{26}$ This measurement was developed by our group ${ }^{27}$ and is a sensitive test for the identification of quadriceps fatigue. ${ }^{7}$ Of the 32 patients, 22 developed quadriceps fatigue; these patients had more glycolytic enzymes and fewer capillaries than nonfatiguers. Importantly, patients who developed fatigue had higher leg-symptom scores, suggesting that fatigue is associated directly with symptom generation.

\section{Anaerobic metabolism at low work rates}

The reduction in oxidative enzymes results in patients with COPD producing lactic acid as a by-product of anaerobic metabolism at much lower rates of exercise compared with agematched controls. ${ }^{10}$ Lactic acid is buffered by bicarbonate to produce carbon dioxide $\left(\mathrm{CO}_{2}\right)$ and water. The lungs can normally excrete $\mathrm{CO}_{2}$, but this is not the case in patients with COPD, who have flow limitation. One would therefore predict that such patients would retain $\mathrm{CO}_{2}$ during whole-body exercise. When we tested this hypothesis in patients with a mean $\mathrm{FEV}_{1}$ of $24 \%$ predicted, we found this to be the case, with a mean rise of $\mathrm{PaCO}_{2}$ during constant-rate treadmill exercise from $5.38 \mathrm{kPa}$ to $6.32 \mathrm{kPa}$ and a fall in $\mathrm{pH}$ from 7.41 to $7.36 .^{28}$

\section{Pulmonary mechanics reduce capacity}

Breathlessness may arise for several reasons. The proposition that pulmonary mechanics limit exercise in COPD is not synonymous with the start of our spiral, patients becoming breathless on exertion. The observation that flow limitation was present in COPD is longstanding, ${ }^{29,30}$ but it has become apparent that increasing lung volumes during exercise dynamic hyperinflation - contribute to symptom generation in $\mathrm{COPD}^{31}$ and a reduction in dynamic hyperinflation can reduce dyspnoea in the absence of changes in $\mathrm{FEV}_{1}{ }^{32,33}$ Dynamic hyperinflation can be measured easily using the inspiratory capacity measurement technique (Fig 3 ) and should form part of future intervention studies.

\section{Are there treatment opportunities in the spiral?}

\section{Preventing development of myopathy}

Pulmonary rehabilitation is an established treatment option ${ }^{34}$ endorsed by the National Institute of Health and Clinical Excellence (NICE), which believes that 'Pulmonary rehabilitation should be made available to all appropriate patients with COPD' (www.nice.org.uk/pdf/CG012_niceguideline.pdf). It is clear that in patients with mild disease, high-intensity pulmonary rehabilitation can elicit a true training benefit ${ }^{35}$ and pulmonary rehabilitation can increase the oxidative enzyme content of skeletal muscle. ${ }^{36}$

If skeletal muscle were to develop weakness in a stepwise manner around exacerbations, as proposed by Spruit et al, ${ }^{22}$ then logically it would be appropriate to target pulmonary rehabilitation around the time of exacerbation. This was done in a study by Man and coworkers, in which patients admitted with acute exacerbation were randomised at discharge to receive usual care or, in addition, to receive pulmonary rehabilitation. ${ }^{37}$ The intervention group had a significant reduction in visits to accident and emergency departments at 3 months (10\% v43\%, $\mathrm{p}=0.01)$ and greater improvement in shuttle walking distance (+90 m v $-25 \mathrm{~m}, \mathrm{p}=0.002)$. Although this approach seems promising, it is unknown whether over a longer period early pulmonary rehabilitation confers a greater advantage than standard pulmonary rehabilitation and, if so, whether this benefit is conferred by improvements in muscle strength.
Fig 3. Example of dynamic hyperinflation induced by exercise in a patient with chronic obstructive pulmonary disease (COPD) in our laboratory. EELV = end expiratory lung volume; EILV = end inspiratory lung volume; TLC = total lung capacity.

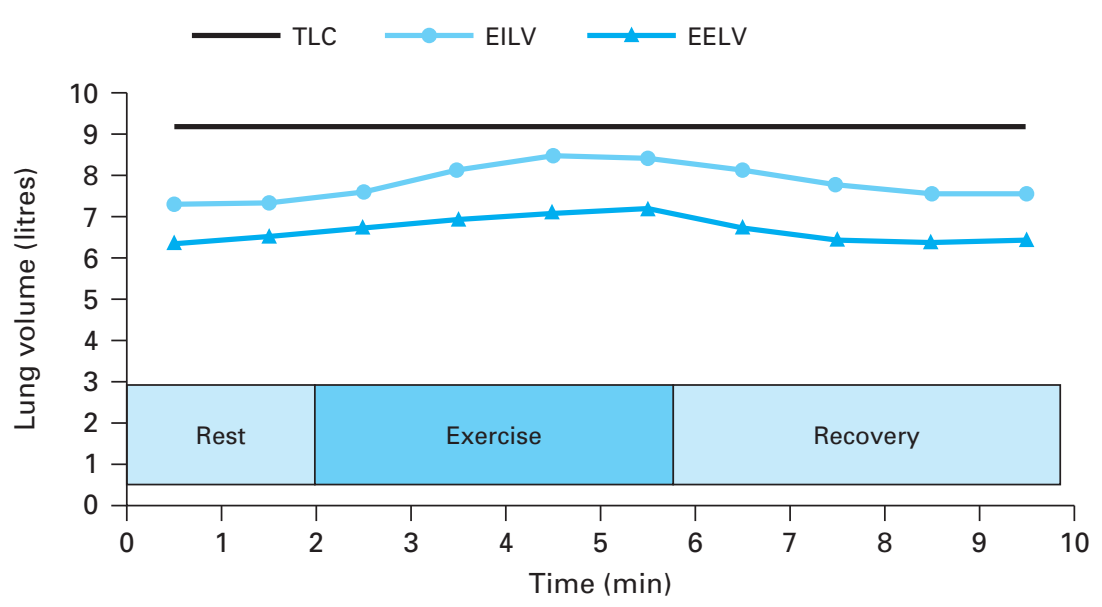




\section{Train the quadriceps muscle}

As noted above, in patients with mild to moderate disease, it is possible to train the quadriceps muscle using pulmonary rehabilitation. However, the same approach does not work in patients with more severe COPD, as they are unable to reach a sufficiently high work intensity. ${ }^{38}$ An alternative approach is to train the quadriceps muscle in isolation using percutaneous electrical stimulation. Two studies have trialled this approach, ${ }^{39,40}$ but although significant benefits have been claimed from these studies the method has not yet moved into general use. One problem is that it is hard to design an appropriate placebo, since the recipient is aware of the electrical stimuli. Therefore, in our own approach to this problem, we have opted to train only one leg and to use the other leg as a control and to assess response in terms of muscle-biopsy appearances and the twitch tension elicited by magnetic stimulation of the femoral nerve, ${ }^{27}$ since these measures are independent of patient effort. Studies are ongoing and we plan to report in early 2007.

\section{Reduce the impact of anaerobic metabolism}

High-intensity exercise in COPD gives rise to acidosis and hypercapnia. Intuitively, approaches to rehabilitation that allow the patient to exercise with reduced minute ventilation could allow the patient to cope better with hypercapnia. Little detailed work has been done in this regard, although it has been established that very-high-intensity supplemental oxygen reduces dynamic hyperinflation, ${ }^{41}$ and this approach is in use by some groups.

An obvious option is to use non-invasive ventilation (NIV) to assist exercise in pulmonary rehabilitation. NIV is an established therapy in the care of patients admitted with acute exacerbations of COPD. ${ }^{42,43}$ When used acutely during exercise in COPD, NIV reduces respiratory muscle work ${ }^{44,45}$ and attenuates exerciseinduced lactataemia. Based on these findings, we hypothesised that NIV given during a PR programme could allow patients to reach a higher level of exercise and therefore achieve a true physiological training benefit. We tested this hypothesis in a prospective randomised controlled study in 19 patients with severe COPD. ${ }^{46}$ The patients receiving NIV during exercise were able to achieve a higher level of exercise and, when studied during a constant-rate exercise test without NIV after the programme, such patients had a 30\% reduction in blood lactate compared with patients who had exercised without NIV (Fig 4). This difference showed a trend towards statistical significance $(\mathrm{p}=0.09)$, and a larger multicentre study to assess the place of NIV in pulmonary rehabilitation is required. Two other studies have addressed this question: one showed benefit ${ }^{47}$ and one did not. ${ }^{48}$ The only clear factor that explains the difference is that our study and that of Costes et al ${ }^{47}$ enrolled patients with more severe disease compared with Bianchi et al ${ }^{48}$ and it seems reasonable that this adjunctive therapy would be most helpful in patients with more severe disease.

\section{Improving pulmonary mechanics}

It has become clear that a variety of drugs may improve pulmonary mechanics in the absence of a clear improvement in $\mathrm{FEV}_{1}$, including beta $_{2}$ agonists, ${ }^{49}$ tiotropium ${ }^{50}$ and low-density gas mixtures. ${ }^{51}$

Lung transplantation, either single or double, may provide a considerable improvement in lung function, ${ }^{52}$ but this is not a therapeutic option for most patients because of the shortage of donor organs and because the mortality of the procedure (15\%
Fig 4. Mean work rates achieved each week in people with chronic obstructive pulmonary disease (COPD) undergoing pulmonary rehabilitation (PR) with (closed symbols) and without (open symbols) the benefit of non-invasive ventilation (NIV). Data from Hawkins et al (2002), reproduced with permission from the BMJ Publishing Group@ BMJ Publishing Group. ${ }^{46}$

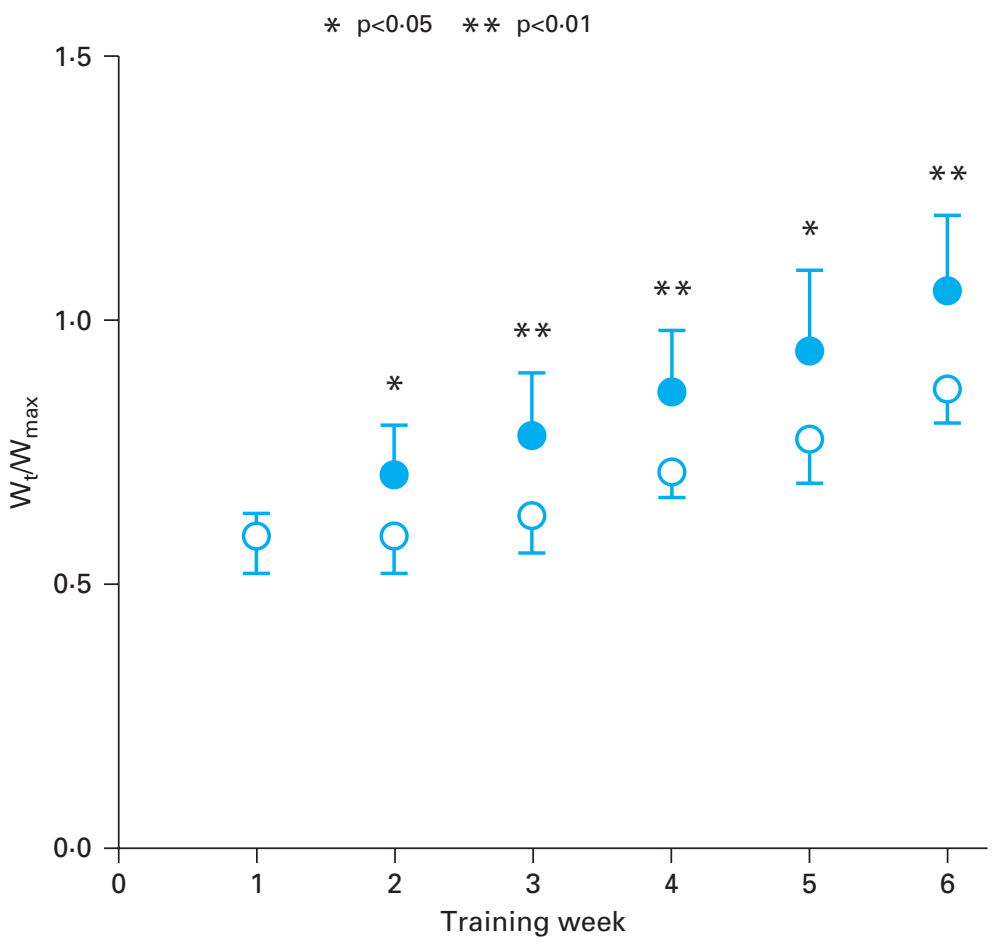


Fig 5. Examples of consecutive $\mathrm{X}$-rays from a responder to bronchoscopic lung volume reduction.

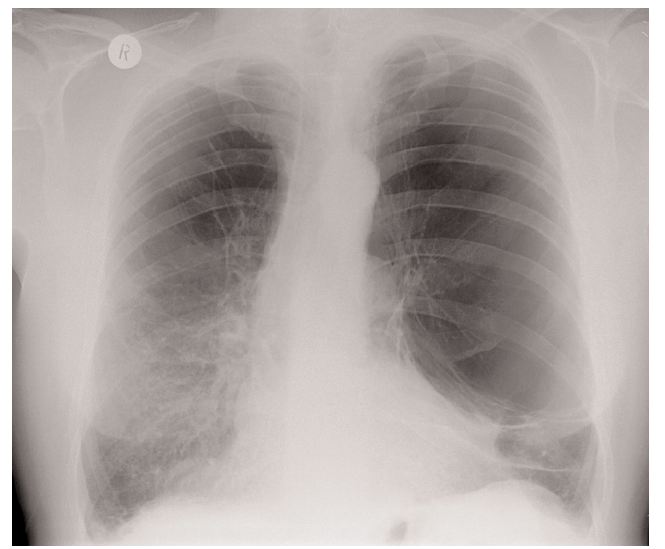

Pre-procedure

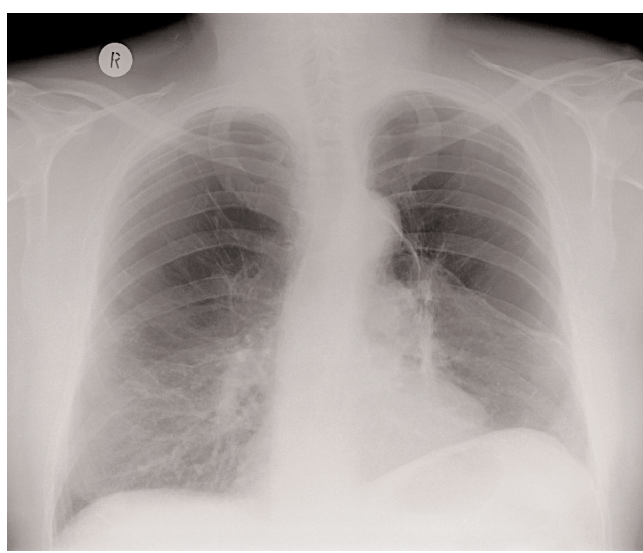

2 days

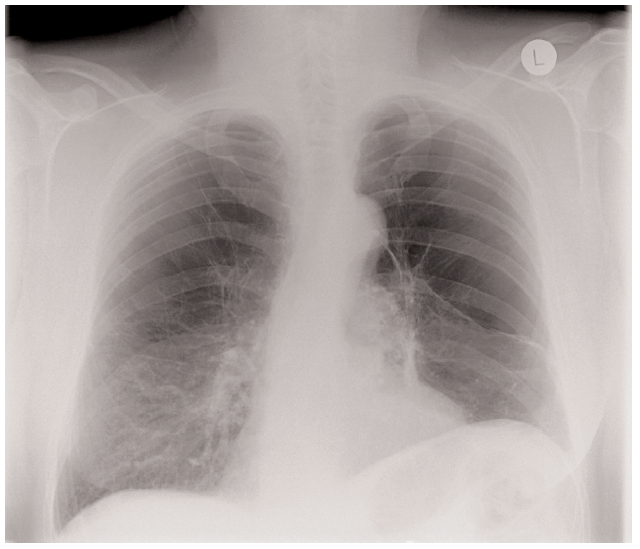

1 day

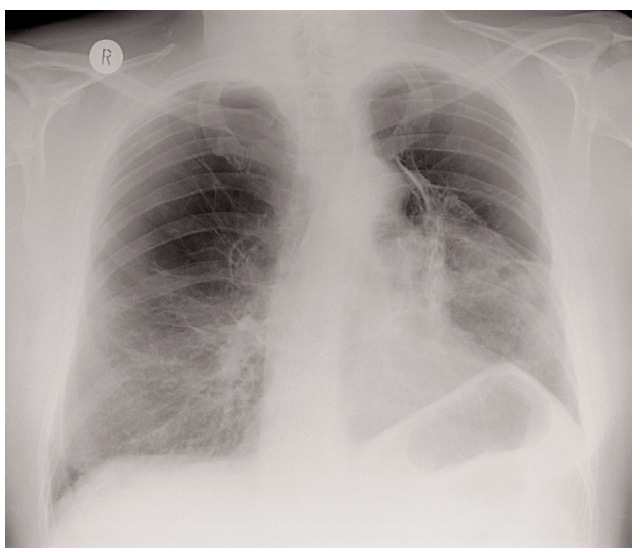

8 days at 1 year, $50 \%$ at 5 years) is unattractive to patients with all but the most severe disease.

Lung-volume reduction surgery (LVRS) was revived in the mid 1990s, ${ }^{53}$ and randomised controlled studies have established that the procedure can improve exercise performance and mortality in patients with heterogeneous upper-zone bullous emphysema. ${ }^{54,55}$ Unfortunately, there are several drawbacks to LVRS. First, the surgery is beneficial only in patients with upperlobe bullous disease, who constitute at most $25 \%$ of patients with emphysema. Second, the mortality rate of approximately $5 \%$ is unattractive to many patients. Third, in order to minimise mortality, most groups, including our own, set minimum fitness criteria for patients being considered for LVRS of a shuttle walk distance of more than $150 \mathrm{~m}$ and a carbon monoxide gas transfer $\left(\mathrm{TL}_{\mathrm{CO}}\right)$ greater than $30 \%$ predicted. In practice, this means that many patients prepared to consider the operation fail on safety criteria. Finally, even in the best hands, improvement does not occur in about $25 \%$ of patients, and no good method of identifying non-responders preoperatively has been found.

It has become a matter of interest to find a less invasive method of achieving lung-volume reduction. Two main approaches have been advocated. One is to create an extra-pulmonary pathway to allow additional drainage of air from the lung. Ex vivo this approach is satisfactory, ${ }^{56}$ but no in vivo data are yet in the public domain. An alternative concept is to place a one-way valve in the airway, which prevents air entering the subtended lobe but allows air to exit. The theory is that the subtended lobe will then collapse, causing volume reduction. This certainly can work (Fig 5); importantly, in series reported from our ${ }^{57,58}$ and other ${ }^{59-61}$ institutions, it seems to be free of major side effects. As with LVRS, a beneficial response is not universal, but the valves can at least be removed if desired. Physiological analysis indicates that improvement in walking distance can be explained almost entirely by a reduction in dynamic hyperinflation and improved ventilation/perfusion matching. ${ }^{58}$ Current thinking is that the best choice of treatment (extra-pulmonary bypass versus endobronchial blocker) may be influenced by the presence or absence of collateral ventilation (desirable with the former approach, not with the latter), and this can be conveniently assessed at bronchoscopy. ${ }^{62}$

\section{Conclusion}

COPD is not simply a pulmonary disease, and consideration of the disease spiral may allow for additional treatment and research opportunities that may be of considerable benefit to patients.

\section{Conflict of interest}

Dr Polkey has received research funding from Emphasys Medical. 


\section{References}

1 Pauwels RA, Buist AS, Calverley PM, Jenkins CR, Hurd SS. Global Strategy for the Diagnosis, Management, and Prevention of Chronic Obstructive Pulmonary Disease. NHLBI/WHO global initiative for chronic obstructive lung disease (GOLD) workshop summary. Am J Respir Crit Care Med 2001;163:1256-76.

2 Fletcher C, Peto R. The natural history of chronic airflow obstruction. BMJ 1977;1:1645-8.

3 Jones PW. Health status measurement in chronic obstructive pulmonary disease. Thorax 2001;56:880-87.

4 Celli BR, Cote CG, Marin JM, Casanova C et al. The body-mass index, airflow obstruction, dyspnea, and exercise capacity index in chronic obstructive pulmonary disease. N Engl J Med 2004;350:1005-12.

5 Williams TJ, Patterson GA, McClean PA, Zamel N, Maurer JR. Maximal exercise testing in single and double lung transplant recipients. Am Rev Respir Dis 1992;145:101-5.

6 Killian KJ, Leblanc P, Martin DH, Summers E et al. Exercise capacity and ventilatory, circulatory, and symptom limitation in patients with chronic airflow limitation. Am Rev Respir Dis 1992;146:935-40.

7 Man WD, Soliman MG, Gearing J, Radford SG et al. Symptoms and quadriceps fatigability after walking and cycling in chronic obstructive pulmonary disease. Am J Respir Crit Care Med 2003;168:562-7.

8 Bernard S, LeBlanc P, Whittom F, Carrier G et al. Peripheral muscle weakness in patients with chronic obstructive pulmonary disease. Am J Respir Crit Care Med 1998;158:629-34.

9 Jakobsson P, Jorfeldt L, Brundin A. Skeletal muscle metabolites and fibre types in patients with advanced chronic obstructive pulmonary disease, with and without chronic respiratory failure. Eur Respir J 1990; 3:192-6.

10 Maltais F, Simard AA, Simard C, Jobin J et al. Oxidative capacity of the skeletal muscle and lactic acid kinetics during exercise in normal subjects and in patients with COPD. Am J Respir Crit Care Med 1996; 153:288-93.

11 Richardson RS, Leek BT, Gavin TP, Haseler LJ et al. Reduced mechanical efficiency in chronic obstructive pulmonary disease but normal peak VO2 with small muscle mass exercise. Am J Respir Crit Care Med 2004;169:89-96.

12 Decramer M, Gosselink R, Troosters T, Verschueren M, Evers G. Muscle weakness is related to utilization of health care resources in COPD patients. Eur Respir J 1997;10:417-23.

13 Marquis K, Debigare R, Lacasse Y, LeBlanc P et al. Midthigh muscle cross-sectional area is a better predictor of mortality than body mass index in patients with chronic obstructive pulmonary disease. Am J Respir Crit Care Med 2002;166:809-13.

14 Couillard A, Prefaut C. From muscle disuse to myopathy in COPD: potential contribution of oxidative stress. Eur Respir J 2005;26:703-19.

15 Hopkinson NS, Man WD, Dayer MJ, Ross ET et al. Acute effect of oral steroids on muscle function in chronic obstructive pulmonary disease. Eur Respir J 2004;24:137-42.

16 Chailleux E, Laaban JP, Veale D. Prognostic value of nutritional depletion in patients with COPD treated by long-term oxygen therapy: data from the ANTADIR observatory. Chest 2003;123:1460-66.

17 Schols AM, Slangen J, Volovics L, Wouters EF. Weight loss is a reversible factor in the prognosis of chronic obstructive pulmonary disease. Am J Respir Crit Care Med 1998;157(6 Pt 1):1791-7.

18 Man WD, Soliman MG, Nikoletou D, Harris ML et al. Non-volitional assessment of skeletal muscle strength in patients with chronic obstructive pulmonary disease. Thorax 2003;58:665-9.

19 Man WD, Hopkinson NS, Harraf F, Nikoletou D et al. Abdominal muscle and quadriceps strength in chronic obstructive pulmonary disease. Thorax 2005;60:718-22.

20 Pitta F, Troosters T, Spruit MA, Probst VS et al. Characteristics of physical activities in daily life in chronic obstructive pulmonary disease. Am J Respir Crit Care Med 2005;171:972-7.

21 Harris ML, Polkey MI, Bath PM, Moxham J. Quadriceps muscle weakness following acute hemiplegic stroke. Clin Rehabil 2001;15:274-81.
22 Spruit MA, Gosselink R, Troosters T, Kasran A et al. Muscle force during an acute exacerbation in hospitalised patients with COPD and its relationship with CXCL8 and IGF-I. Thorax 2003;58:752-6.

23 Creutzberg EC, Schols AM, Weling-Scheepers CA, Buurman WA, Wouters EF. Characterization of nonresponse to high caloric oral nutritional therapy in depleted patients with chronic obstructive pulmonary disease. Am J Respir Crit Care Med 2000;161(3 Pt 1):745-52.

24 Debigare R, Marquis K, Cote CH, Tremblay RR et al. Catabolic/anabolic balance and muscle wasting in patients with COPD. Chest 2003;124: 83-9.

25 Hopkinson NS, Nickol AH, Payne J, Hawe E et al. Angiotensin converting enzyme genotype and strength in chronic obstructive pulmonary disease. Am J Respir Crit Care Med 2004;170:395-9.

26 Saey D, Michaud A, Couillard A, Cote $\mathrm{CH}$ et al. Contractile fatigue, muscle morphometry, and blood lactate in chronic obstructive pulmonary disease. Am J Respir Crit Care Med 2005;171:1109-15.

27 Polkey MI, Kyroussis D, Hamnegard C-H, Mills GH et al. Quadriceps strength and fatigue assessed by magnetic stimulation of the femoral nerve in man. Muscle Nerve 1996;19:549-55.

28 Polkey MI, Hawkins P, Kyroussis D, Ellum SG et al. Inspiratory pressure support prolongs exercise induced lactataemia in severe COPD. Thorax 2000;55:547-9.

29 Dayman H. Mechanics of breathing in health and emphysema. J Clin Invest 1951;30:1175-90.

30 Christie RV. The elastic properties of the emphysematous lung and their clinical significance. J Clin Invest 1934;13:295-319.

31 O'Donnell DE, Revill SM, Webb KA. Dynamic hyperinflation and exercise intolerance in chronic obstructive pulmonary disease. Am J Respir Crit Care Med 2001;164:770-77.

32 Man WD, Mustfa N, Nikoletou D, Kaul S et al. Effect of salmeterol on respiratory muscle activity during exercise in poorly reversible COPD. Thorax 2004;59:471-6.

33 Hadcroft J, Calverley PM. Alternative methods for assessing bronchodilator reversibility in chronic obstructive pulmonary disease. Thorax 2001;56:713-20.

34 Griffiths TL, Burr ML, Campbell IA, Lewis-Jenkins V et al. Results at 1 year of outpatient multidisciplinary pulmonary rehabilitation: a randomised controlled trial. Lancet 2000;355:362-8.

35 Casaburi R, Patessio A, Ioli F, Zanaboni $\mathrm{S}$ et al. Reductions in exercise lactic acidosis and ventilation as a result of exercise training in patients with obstructive lung disease. Am Rev Respir Dis 1991;143:9-18.

36 Maltais F, LeBlanc P, Simard C, Jobin J et al. Skeletal muscle adaptation to endurance training in patients with chronic obstructive pulmonary disease. Am J Respir Crit Care Med 1996;154(2 Pt 1):442-7.

37 Man WD, Polkey MI, Donaldson N, Gray BJ, Moxham J. Community pulmonary rehabilitation after hospitalisation for acute exacerbations of chronic obstructive pulmonary disease: randomised controlled study. BMJ 2004;329:1209.

38 Casaburi R, Porszasz J, Burns MR, Carithers ER et al. Physiologic benefits of exercise training in rehabilitation of patients with severe chronic obstructive pulmonary disease. Am J Respir Crit Care Med 1997;155: 1541-51.

39 Neder JA, Sword D, Ward SA, Mackay E et al. Home based neuromuscular electrical stimulation as a new rehabilitative strategy for severely disabled patients with chronic obstructive pulmonary disease (COPD). Thorax 2002;57:333-7.

40 Bourjeily-Habr G, Rochester CL, Palermo F, Snyder P, Mohsenin V. Randomised controlled trial of transcutaneous electrical muscle stimulation of the lower extremities in patients with chronic obstructive pulmonary disease. Thorax 2002;57:1045-9.

41 Somfay A, Porszasz J, Lee SM, Casaburi R. Dose-response effect of oxygen on hyperinflation and exercise endurance in non-hypoxemic COPD patients. Eur Respir J 2001;18:77-84.

42 Plant PK, Owen JL, Elliott MW. Early use of non-invasive ventilation for acute exacerbations of chronic obstructive pulmonary disease on general respiratory wards: a multicentre randomised controlled trial. Lancet 2000;355:1931-5. 
43 Bott J, Carroll MP, Conway JH, Keilty SEJ et al. Randomised controlled trial of nasal ventilation in acute respiratory failure due to chronic obstructive airways disease. Lancet 1993;341:1555-7.

44 Polkey MI, Kyroussis D, Mills GH, Hamnegard C-H et al. Inspiratory pressure support reduces slowing of inspiratory muscle relaxation rate during exhaustive treadmill walking in severe COPD. Am J Respir Crit Care Med 1996;154:1146-50.

45 Kyroussis D, Polkey MI, Hamnegard CH, Mills GH et al. Respiratory muscle activity in patients with COPD walking to exhaustion with and without pressure support. Eur Respir J 2000;15:649-55.

46 Hawkins P, Johnson LC, Nikoletou D, Hamnegard $\mathrm{CH}$ et al. Proportional assist ventilation as an aid to exercise training in severe chronic obstructive pulmonary disease. Thorax 2002;57:853-9.

47 Costes F, Agresti A, Court-Fortune I, Roche F et al. Noninvasive ventilation during exercise training improves exercise tolerance in patients with chronic obstructive pulmonary disease. J Cardiopulm Rehabil 2003;23:307-13.

48 Bianchi L, Foglio K, Pagani M, Vitacca M et al. Effects of proportional assist ventilation on exercise tolerance in COPD patients with chronic hypercapnia. Eur Respir J 1998;11:422-7.

49 O’Donnell DE, Voduc N, Fitzpatrick M, Webb KA. Effect of salmeterol on the ventilatory response to exercise in chronic obstructive pulmonary disease. Eur Respir J 2004;24:86-94.

50 Celli B, ZuWallack R, Wang S, Kesten S. Improvement in resting inspiratory capacity and hyperinflation with tiotropium in COPD patients with increased static lung volumes. Chest 2003;124:1743-8.

51 Palange P, Valli G, Onorati P, Antonucci R et al. Effect of heliox on lung dynamic hyperinflation, dyspnea, and exercise endurance capacity in COPD patients. J Appl Physiol 2004;97:1637-42.

52 Martinez FJ, Orens JB, Whyte RI, Graf L et al. Lung mechanics and dyspnea after lung transplantation for chronic airflow obstruction. Am J Respir Crit Care Med 1996;153:1536-43.

53 Cooper J, Patterson G, Sundaresan R, Trulock E et al. Results of 150 consecutive bilateral lung volume reduction procedures in patients with severe emphysema. J Thorac Cardiovasc Surg 1996;112:1319-30.
54 Geddes D, Davies M, Koyama H, Hansell D et al. Effect of lung-volumereduction surgery in patients with severe emphysema. $N$ Engl J Med 2000;343:239-45

55 Fishman A, Martinez F, Naunheim K, Piantadosi S et al. A randomized trial comparing lung-volume-reduction surgery with medical therapy for severe emphysema. N Engl J Med 2003;348:2059-73.

56 Lausberg HF, Chino K, Patterson GA, Meyers BF et al. Bronchial fenestration improves expiratory flow in emphysematous human lungs. Ann Thorac Surg 2003;75:393-8.

57 Toma TP, Hopkinson N, Hillier J, Hansell DM et al. Bronchoscopic volume reduction with valve implants in patients with severe emphysema. Lancet 2003;361:931-3.

58 Hopkinson NS, Toma TP, Hansell DM, Goldstraw P et al. Effect of bronchoscopic lung volume reduction on dynamic hyperinflation and exercise in emphysema. Am J Respir Crit Care Med 2005;171:453-60.

59 Snell G, Holsworth L, Borrill ZL, Thomson KR et al. The potential for bronchoscopic lung volume reduction using bronchial prostheses. Chest 2003;124:1073-80.

60 Yim AP, Hwong TM, Lee TW, Li WW et al. Early results of endoscopic lung volume reduction for emphysema. J Thorac Cardiovasc Surg 2004; 127:1564-73.

61 Venuta F, de Giacomo T, Rendina EA, Ciccone AM et al. Bronchoscopic lung-volume reduction with one-way valves in patients with heterogeneous emphysema. Ann Thorac Surg 2005;79:411-7.

62 Morrell NW, Wignall BK, Biggs T, Seed WA. Collateral ventilation and gas exchange in emphysema. Am J Respir Crit Care Med 1994;150: 635-41. 